\title{
REGRESI LINIER BERGANDA DAN SPATIAL DURBIN MODEL UNTUK MENGIDENTIFIKASI FAKTOR-FAKTOR YANG MEMPENGARUHI GIZI BURUK BALITA DI KOTA MEDAN
}

\author{
Ade Maulina Panjaitan ${ }^{1}$, Susiana $^{2}$ \\ ${ }^{1,2}$ Jurusan Matematika FMIPA, Universitas Negeri Medan \\ Email: panjaitanademaulina@gmail.com
}

\begin{abstract}
ABSTRAK
Kasus gizi buruk di kota Medan terus mengalami peningkatan dibandingkan dengan tahuntahun sebelumnya. Pada tahun 2015, Kota Medan berada pada peringkat ke-2 kasus gizi buruk balita terbanyak di Sumatera Utara. Penelitian ini bertujuan untuk mengidentifikasi faktor-faktor yang mempengaruhi gizi buruk balita di kota Medan dan menentukan model terbaik yang dapat menggambarkan gizi buruk balita di kota Medan. Analisis yang digunakan adalah regresi linier berganda dengan Ordinary Least Square (OLS) dan Spatial Durbin Model (SDM). Berdasarkan analisis Moran's I, diperoleh adanya dependensi spasial pada variabel angka gizi buruk balita di kota Medan serta beberapa faktor yang mempengaruhinya. Dengan demikian perlu dilakukan analisis spasial model SDM. Dari hasil penelitian, diperoleh model SDM menghasilkan R-square sebesar 0.703 dan AIC sebesar 117.2534. variabel yang secara signifikan mempengaruhi gizi buruk balita di kota Medan dengan model SDM adalah banyaknya balita yang mendapat imunisasi lengkap $\left(X_{7}\right)$ dan banyaknya rumah tangga miskin $\left(X_{10}\right)$.
\end{abstract}

Kata kunci : gizi buruk, dependensi spasial, Spatial Durbin Model, Ordinary Least Square

\begin{abstract}
Cases of malnutrition in the city of Medan continues to increase compared with previous years. In 2015, the city of Medan is ranked 2nd malnutrition of children under five in North Sumatra. This study aims to identify factors that affect infant malnutrition in the city of Medan and determine the best model to describe malnourished children under five in the city of Medan. The analysis used is multiple linear regression with ordinary least squares (OLS) and Spatial Durbin Model (SDM). Based on the analysis of Moran's I, obtained their spatial dependencies in the variable infant malnutrition rate in the city of Medan as well as some of the factors that influence it. Thus the need to analyze the spatial model of HR. From the research results, obtained SDM models produce $R$-square of 0703 and AIC at 117.2534. variables that significantly affect malnourished children under five in the city of Medan with human models is the number of infants are fully immunized $\left(X_{7}\right)$ and the number of poor households $\left(X_{10}\right)$.
\end{abstract}

Keywords: malnutrition, spatial dependencies, Spatial Durbin Model, Ordinary Least Square 


\section{Latar Belakang}

Gizi buruk merupakan masalah yang masih menjadi perhatian utama hingga saat ini, terutama di negara-negara berkembang. Tercatat sekitar sepertiga dari populasi balita yang ada di negara-negara berkembang mengalami masalah gizi buruk. Jika penderita dapat bertahan hingga dewasa, maka penderita akan beresiko mengalami perkembangan kognitif yang buruk dan produktivitas yang rendah [1].

Salah satu indikator dari derajat kesehatan adalah status gizi. Status gizi merupakan salah satu faktor yang penting untuk membentuk sumber daya manusia yang bermutu. Status gizi bayi dapat dilihat dari berat bayi waktu lahir, status gizi bayi lahir dengan berat badan rendah $(<2.500 \mathrm{gr})$ atau disebut BBLR. Bersumber dari Bidang Pelayanan Kesehatan Dinas Kesehatan Kota Medan, pada tahun 2015 tercatat 49.251 bayi baru lahir ditimbang, dimana dari jumlah tersebut terdapat 110 bayi $(0,2 \%)$ berstatus BBLR dengan rincian laki-laki sebanyak 56 bayi dan perempuan sebanyak 54 bayi.

Kasus gizi buruk balita di kota Medan terus mengalami peningkatan dibandingkan dengan tahun-tahun sebelumnya yakni tahun 2013 ditemukan 65 kasus gizi buruk pada balita di kota Medan dimana terdapat 38 balita laki-laki dan 27 balita perempuan, tahun 2014 ditemukan 84 kasus gizi buruk pada balita di kota Medan dimana ter dapat 43 balita laki-laki dan 41 balita perempuan. Sedangkan tahun 2015 ditemukan 111 kasus gizi buruk balita di kota Medan dimana terdapat 62 balita laki-laki dan 49 balita perempuan [2] Metode Ordinary Least Square (OLS) tidak tepat digunakan apabila observasi yang diteliti mengandung informasi ruang atau spasial. Karena itu digunakan metode Regresi Spasial yang merupakan pengembangan dari metode Analisis Regresi Linier, di mana aspek lokasi juga ikut diperhatikan [3]

Salah satu model spasial autoregressive adalah model spatial mixed autoregressive [3] memiliki bentuk persamaan seperti spatial autoregressive model (SAR), dengan pengaruh spasial lag hanya pada veriabel dependen. Spatial Durbin Model (SDM) merupakan salah satu dari jenis model tersebut yang dikembangkan dalam beberapa kasus hubungan dependensi spasial tidak hanya terjadi pada variabel dependen, tetapi juga pada variabel independen sehingga ditambahkan spasial lag WX. Regresi spasial merupakan hasil pengembangan dari metode regresi linier sederhana. Pengembangan itu didasarkan pengaruh tempat atau spasial pada data yang dianalisis [3]. 


\section{Tinjauan Pustaka}

\section{Gizi Buruk}

Gizi buruk merupakan suatu kondisi kekurangan gizi pada tingkatan yang sudah berat, dimana status gizinya berada jauh di bawah standar. Gizi buruk akan terjadi manakala kebutuhan tubuh akan kalori, protein, atau bahkan keduanya tidak tercukupi. Ada tiga jenis status gizi buruk karena kekurangan protein (kwashiorkor), kekurangan karbohidrat (marasmus), dan kekurangan keduanya (marasmic-kwashiorkor). Gizi buruk berpeluang untuk menyerang siapa saja, terutama bayi dan anak-anak yang tengah berada pada masa pertumbuhan [4].

\section{Regresi Linier Berganda}

Analisis regresi adalah metode statistika yang digunakan untuk memodelkan hubungan antara variabel respon (Y) dengan variabel prediktor (X). Secara umum hubungan tersebut dapat dinyatakan sebagai berikut:

$$
y=\beta_{0}+\beta_{1} X_{1}+\cdots+\beta_{k} X_{k}+\varepsilon
$$

dimana $\beta_{0}, \beta_{1}, \beta_{k}$ adalah parameter yang tidak diketahui, dan $\varepsilon$ adalah error regresi.

\section{Estimasi Parameter Model Regresi}

Estimasi parameter untuk $\beta$ dapat diperoleh dengan metode kuadrat terkecil (Ordinary Least Square). Bentuk penaksir Least Square adalah:

$$
\widehat{\beta}=\left(X^{T} X\right)^{-1} X^{T} y
$$

\section{Pengujian parameter Model Regresi Linier}

\section{Uji Serentak (Uji F)}

Statistik uji :

$$
F_{\text {hitung }}=\frac{M S R}{M S E}
$$

Untuk suatu nilai $\alpha$ yang diberikan daerah kritis $F_{\text {hitung }}>F_{\alpha(k, n-k-1)}$ dengan $f_{\text {hit }}$ adalah $F_{\text {hitung }}, k$ adalah banyaknnya variabel bebas, dan $n$ adalah banyaknya observasi. 


\section{Uji Parsial (Uji t)}

Statistik uji :

$$
t_{\text {hitung }}=\frac{\hat{\beta}_{j}}{S E\left(\hat{\beta}_{j}\right)}
$$

Jika taraf signifikansi sebesar $\alpha$, maka tolak $H_{0}$ jika $\left|t_{\text {hitung }}\right|>t_{\left(\frac{\alpha}{2}, n-k-1\right)}$ berarti ada pengaruh antara variabel prediktor terhadap variabel respon dan tidak ditolak tolak $H_{0}$ jika $\left|t_{\text {hitung }}\right|<t_{\left(\frac{\alpha}{2}, n-k-1\right)}$ berarti tidak ada pengaruh antara variabel prediktor terhadap variabel respon.

\section{Uji Asumsi}

\section{Uji Normalitas Residual}

Salah satu metode yang dapat digunakan untuk mendeteksi asumsi normalitas adalah Kolmogorov-Smirnov.

Statistik uji :

$$
D=\operatorname{maks}\left|F_{0}(x)-S_{N}(x)\right|
$$

\section{Uji Multikolinieritas}

Salah satu cara untuk menguji multikolinieritas dalam model regresi adalah dengan melihat nilai TOL (Tolerance) dan Variance Inflation Factor (VIF) dari masing-masing variabel prediktor terhadap variabel respon [5]

\section{Uji Autokolerasi}

Cara mendeteksi keberadaan autokolerasi yaitu dengan menggunakan uji Durbin-Watson.

\section{Uji Heteroskedastisitas}

Heterokedastisitas terjadi apabila variasi $\varepsilon_{i}$ tidak konstan atau berubah-ubah secara sistematik seiring berubahnya nilai variabel prediktor, untuk mengujinya digunakan uji Gleser [5]

\section{Analisis Regresi Spasial}

Model umum regresi spasial dapat dinyatakan dalam persamaan berikut [6]. 
$\boldsymbol{y}=\rho \boldsymbol{W}_{\mathbf{1}} \boldsymbol{y}+\boldsymbol{X} \boldsymbol{\beta}+\boldsymbol{u}, \boldsymbol{u}=\lambda \boldsymbol{W}_{\mathbf{2}} \boldsymbol{u}+\varepsilon, \varepsilon \sim N\left(0, \sigma^{2} \boldsymbol{I}\right)$

Pendugaan parameter pada model umum persamaan regresi spasial dalam bentuk matriks [3] yaitu:

$$
\widehat{\beta}=\left(X^{T} X\right)^{-1} X^{T}(I-\rho W) y
$$

Beberapa model umum di atas, dapat diperoleh beberapa model berikut:

\section{Spatial Autoregressive Model (SAR)}

jika nilai $\rho \neq 0$ atau $\lambda=0$ maka model regresi spasial akan menjadi model regresi Spatial Autoregressive Model (SAR) seperti pada persamaan (5).

$$
\boldsymbol{y}=\rho \boldsymbol{W}_{\mathbf{1}} \boldsymbol{y}+\boldsymbol{X} \boldsymbol{\beta}+\boldsymbol{\varepsilon}, \boldsymbol{\varepsilon} \sim N\left(0, \sigma^{2} \mathbf{I}\right)
$$

\section{Spatial Error Model (SEM)}

jika nilai $\lambda \neq 0$ atau $\rho=0$ maka akan menjadi model Spatial error Model (SEM) seperti pada persamaan (6).

$$
\boldsymbol{y}=\boldsymbol{X} \boldsymbol{\beta}+\lambda \boldsymbol{W}_{\mathbf{2}} \boldsymbol{u}+\boldsymbol{\varepsilon}, \boldsymbol{\varepsilon} \sim N\left(0, \sigma^{2} \boldsymbol{I}\right)
$$

\section{Spatial Autoregressive Moving Average (SARMA)}

Jika $\boldsymbol{W}_{1}, \boldsymbol{W}_{\mathbf{2}} \neq 0, \lambda \neq 0$, atau $\rho \neq 0$ maka disebut model Spatial Autoregressive Moving Average (SARMA) seperti pada persamaan (3).

\section{Ordinary Least Square (OLS)}

Jika $\rho=0$ dan $\lambda=0$ maka akan menjadi model regresi linier sederhana dimana estimasi parameternya dapat dilakukan melalui Ordinary Least Square (OLS) seperti pada persamaan (7).

$$
\boldsymbol{y}=\boldsymbol{X} \boldsymbol{\beta}+\boldsymbol{\varepsilon}, \boldsymbol{\varepsilon} \sim N\left(0, \sigma^{2} \boldsymbol{I}\right)
$$

\section{Spatial Durbin Model}

Spatial Durbin Model (SDM) merupakan model regresi spasial yang memiliki bentuk seperti Spatial Autoregressive Model (SAR) yang memiliki spasial lag pada variabel respon $(Y)$ seperti persamaan berikut:

$$
Y=\rho W_{1} y+X \beta+\varepsilon
$$


Sedangkan Spatial Durbin Model tidak hanya memiliki spasial lag pada variabel respon, Spatial Durbin Model juga memiliki spasial lag pada variabel penjelas [3] Model SDM dinyatakan pada persamaan berikut:

$$
y_{i}=\rho \sum_{j=1}^{n} w_{i j} y_{j}+\alpha+\sum_{p=1}^{k} \beta_{p} x_{i p}+\sum_{p=1}^{k} \sum_{j=1}^{n} \theta_{p}\left(w_{i j} x_{p j}\right)+\varepsilon_{i}
$$

\section{Estimasi Parameter Spatial Durbin Model}

Estimasi parameter Spatial Durbin Model (SDM) dilakukan dengan menggunakan metode Maximum Likelihood Estimation (MLE). Langkah pertama adalah dengan membentuk fungsi likelihood. Diperoleh estimasi parameter $\rho$ pada persamaan (9), estimasi parameter $\delta$ pada persamaan (10), dan estimasi parameter $\sigma^{2}$ pada persamaan (11).

$$
\begin{gathered}
\ln (L(\rho))=C-\frac{n}{2} \ln \left(\left(\boldsymbol{e}_{\mathbf{0}}-\rho \boldsymbol{e}_{\boldsymbol{d}}\right)^{\boldsymbol{T}}\left(\boldsymbol{e}_{\mathbf{0}}-\rho \boldsymbol{e}_{\boldsymbol{d}}\right)\right)+\ln \left|\boldsymbol{I}-\rho \boldsymbol{W}_{\mathbf{1}}\right| \\
\widehat{\boldsymbol{\delta}}=\widehat{\boldsymbol{\delta}}_{\mathbf{0}}-\rho \widehat{\boldsymbol{\delta}}_{\boldsymbol{d}} \\
\widehat{\boldsymbol{\sigma}}^{2}=\frac{\left\{\left[\boldsymbol{e}_{\mathbf{0}}-\boldsymbol{\rho} \boldsymbol{e}_{\boldsymbol{d}}\right]^{T}\left[\boldsymbol{e}_{\mathbf{0}}-\boldsymbol{\rho} \boldsymbol{e}_{\boldsymbol{d}}\right]\right\}}{\boldsymbol{n}}
\end{gathered}
$$

\section{Pengujian Model SDM}

\section{Uji Kesesuaian Model}

Statistik uji dinyatakan pada persamaan berikut [7]

$$
F_{\text {hitung }}=\frac{(S S T-S S E) / k}{S S E /(n-k-1)}
$$

\section{Uji Signifikansi Parameter}

Pengujian signifikansi parameter pemodelan spasial pada penelitian ini menggunakan uji Wald [3]

Pengujian untuk menguji parameter $\rho$ :

$$
\text { Wald }_{\rho}=\frac{\hat{\rho}^{2}}{\operatorname{var}(\hat{\rho})}
$$

Pengujian untuk menguji parameter $\beta$ :

$$
\operatorname{Wald}_{\beta}=\frac{\hat{\beta}_{j}{ }^{2}}{\operatorname{var}\left(\hat{\beta}_{j}\right)}
$$


Pengujian untuk menguji parameter $\theta$ :

$$
\operatorname{Wald}_{\theta}=\frac{\hat{\theta}_{j}^{2}}{\operatorname{var}\left(\hat{\theta}_{j}\right)}
$$

Pengambilan keputusan adalah $H_{0}$ ditolak jika nilai Wald $>\chi_{(\alpha, 1)}^{2}$

\section{Uji Efek Spasial}

\section{Uji Dependensi Spasial}

Uji dependensi spasial atau autokolerasi antar lokasi dilakukan dengan menggunakan metode Moran's $I\left(I_{m}\right)$. Statistik uji [8]

$$
Z_{\text {hitung }}=\frac{I-E(I)}{\sqrt{\operatorname{var}(I)}}
$$

Daerah keputusan : $H_{0}$ ditolak jika $\left|Z_{\text {hitung }}\right|>Z_{\alpha / 2}$. Nilai $I$ berada pada kisaran antara -1 dan 1.

Pola penyebaran antar lokasi dapat dilihat dalam Moran's scatterplot yang menunjukkan hubungan antara nilai amatan pada suatu lokasi yang distandarkan dengan ratarata amatan pada lokasi-lokasi yang diamati. Moran's scatterplot terdiri dari empat kuadran, yaitu kuadran I (High-High), Kuadran II (Low-High), kuadran III (Low-Low), kuadran IV (High-Low).

\section{Uji Heterogenitas Spasial}

Pengujian ini menunjukkan adanya keragaman antarlokasi dimana setiap lokasi memiliki struktur dan parameter hubungan yang berbeda. Untuk melakukan pengujian heterogenitas spasial digunakan metode Breusch-Pagan Test [3Nilai Breusch-Pagan test:

$$
B P=\frac{1}{2} f^{T} Z\left(Z^{T} Z\right)^{-1} Z^{T} f \sim \chi_{(k)}^{2}
$$

Daerah keputusan : $H_{0}$ ditolak jika $B P>\chi^{2}{ }_{(\alpha ; k)}$

\section{Matriks Pembobot Spasial}

Matriks pembobot spasial digunakan untuk menentukan bobot antar lokasi yang diamati berdasarkan hubungan ketetanggaan antar lokasi. Jenis-jenis matriks pembobot spasial, antara lain: Rook Contiguity, Bishop Contiguity, Queen Contiguity. 
Matriks pembobot spasial $w_{i j}$ yang terbentuk berukuran $\mathrm{n} \times \mathrm{n}$, dimana setiap elemen matriks menggambarkan ukuran kedekatan antara pengamatan i dan j. Matriks pembobot spasial mendefinisikan $w_{i j}=1$ jika lokasi bersinggungan sisi atau sudut bahkan sisi dan sudut sesuai jenis ketetanggaan di atas dan $w_{i j}=0$ untuk lokasi lainnya [6]

\section{Pemilihan Model Terbaik}

Pemilihan model terbaik ditentukan melalui nilai koefisien determinasi $\left(R^{2}\right)$ dan Akaike's Information Criterion (AIC).

\section{Koefisien determinasi $\left(R^{2}\right)$}

$$
R^{2}=1-\frac{S S E}{S S T}
$$

Dimana SSE adalah jumlah kuadrat error dan SST adalah jumlah kuadrat total.

Nilai dari koefisien determinasi berada pada kisaran $0 \leq R^{2} \leq 1$. Besarnya nilai $R^{2}$ menunjukkan besarnya tingkat kepercayaan terhadap model.

\section{Akaike's Information Criterion (AIC)}

$$
A I C=-2 \log (L(\hat{\theta} \mid y))+2 k
$$

Model terbaik ditentukan berdasarkan nilai AIC yang paling kecil.

\section{Metode Penelitian}

Data yang digunakan adalah data sekunder dari Dinas Kesehatan Kota Medan pada tahun 2015. Data yang diperlukan dalam penelitian ini adalah Banyaknya balita penderita gizi buruk (Y), Presentase bayi yang diberi ASI eksklusif $\left(X_{1}\right)$, Banyaknya bayi dengan berat badan lahir rendah (BBLR) $\left(X_{2}\right)$, Banyaknya rumah sehat $\left(X_{3}\right)$, Penduduk dengan akses berkelanjutan terhadap air minum berkualitas (layak) $\left(X_{4}\right)$, Banyaknya posyandu $\left(X_{5}\right)$, Penduduk dengan akses terhadap fasilitas sanitasi layak (jamban sehat) $\left(X_{6}\right)$, Banyaknya balita yang mendapat imunisasi lengkap $\left(X_{7}\right)$, Banyaknya kunjungan ibu hamil $\left(X_{8}\right)$, Banyaknya tenaga kesehatan di fasilitas kesehatan $\left(X_{9}\right)$, dan Banyaknya rumah tangga miskin $\left(X_{10}\right)$.

Tahapan yang dilakukan dalam penelitian ini adalah: 
1. Langkah-langkah dalam melakukan pemodelan regresi linier berganda dengan metode OLS adalah sebagai berikut:

- Memodelkan variabel respon (Y) dengan variabel prediktor (X).

- Melakukan pengujian kesesuaian model, untuk mengetahui apakah model yang terbentuk sudah sesuai atau belum.

- Melakukan pengujian uji signifikansi parameter, untuk mengetahui variabel apa saja yang berpengaruh secara signifikan terhadap model.

- Melakukan uji asumsi model regresi klasik, yaitu uji normalitas residual, uji multikolinieritas, uji autokolerasi, dan uji heterokedastisitas.

2. Mengidentifikasi faktor-faktor gizi buruk balita di kota Medan menggunakan regresi linier berganda dengan metode Ordinary Least Square (OLS).

3. Melakukan pemodelan Spatial Durbin Model (SDM) dengan langkah-langkah sebagai berikut:

- Menentukan matriks pembobot spasial (W) dengan metode Queen Contiguity.

- Melakukan uji efek spasial meliputi uji dependensi spasial dengan menggunakan Moran's I pada setiap variabel dilanjutkan dengan Moran's scatterplot untuk mengetahui penyebaran antarlokasi dan uji heterogenitas spasial dengan BreuschPagan Test.

- Melakukan estimasi parameter model SDM.

- Melakukan uji signifikansi parameter model SDM.

- Melakukan uji asumsi residual model SDM.

4. Mengidentifikasi faktor-faktor gizi buruk ballita di kota Medan menggunakan Spatial Durbin Model (SDM).

5. Membandingkan dan interpretasi hasil analisis regresi linier berganda dengan metode Ordinary Least Square (OLS) dan Spatial Durbin Model (SDM) dalam kasus gizi buruk balita di kota Medan dengan melakukan pemilihan model terbaik menggunakan $R$-square terbesar dan $A I C$ terkecil.

\section{Hasil dan Pembahasan}

\subsection{Deskripsi Data}

Kota Medan untuk kasus gizi buruk termasuk kategori tinggi (nomor 2)di Sumatera Utara. Dinas Kesehatan Kota Medan mencatat ada 111 kasus gizi buruk yang terjadi di 
Medan Tahun 2015. Setiap tahun kasus ini selalu saja ditemukan, khususnya Kota Medan. Di Medan, hampir setiap kecamatan terdapat kasus gizi buruk. Kasus terbanyak, terdapat di M. Marelan dengan 20 balita penderita gizi buruk, M. Labuhan dengan 18 balita penderita gizi buruk, M. Helvetia dengan 10 balita penderita gizi buruk.

\subsection{Regresi Linier Berganda}

Hasil regresi diketahui bahwa terjadi multikolinieritas pada data ditunjukkan dengan adanya nilai VIF yang lebih dari 10. Dalam model regresi diharapkan tidak terjadi multikolinieritas. Untuk mengatasi terjadi multikolinieritas perlu dilakukan eliminasi terhadap variabel prediktor yang tidak berpengaruh terhadap variabel respon dengan menggunakan metode stepwise backward. Dengan metode stepwise backward, diperoleh empat variabel yang signifikan terhadap angka banyaknya balita penderita gizi buruk yaitu Banyaknya bayi dengan berat badan lahir rendah (BBLR) $\left(X_{2}\right)$, Penduduk dengan akses berkelanjutan terhadap air minum berkualitas (layak) $\left(X_{4}\right)$, Banyaknya balita yang mendapat imunisasi lengkap $\left(X_{7}\right)$, Banyaknya rumah tangga miskin $\left(X_{10}\right)$. Estimasi parameter variable signifikan yaitu $X_{2}, X_{4}, X_{7}, X_{10}$ pada $\alpha=5 \%$ ditunjukkan pada Tabel 2 berikut.

Tabel 1: Estimasi Parameter OLS

\begin{tabular}{|c|c|c|c|c|}
\hline Variabel & Nilai $\beta$ & $t_{\text {hitung }}$ & Sig. & VIF \\
\hline$Y$ & 0.223 & 0.083 & 0.935 & \\
\hline$X_{2}$ & -0.203 & -2.354 & 0.032 & 1.355 \\
\hline$X_{4}$ & 0.000001 & -3.346 & 0.004 & 1.487 \\
\hline$X_{7}$ & 0.004 & 2.411 & 0.028 & 2.236 \\
\hline$X_{10}$ & 0.001 & 0.024 & 0.024 & 2.167 \\
\hline
\end{tabular}

Berdasarkan Tabel 1, maka model yang terbentuk adalah:

$$
y=0.223-0.203 X_{2}+0.000001 X_{4}+0.004 X_{7}+0.001 X_{10}+\varepsilon
$$




\section{i. Pengujian Parameter Model Regresi Linier}

\section{Uji serentak (Uji F)}

Nilai $F_{\text {hitung }}=9.477>F_{0.05,4,16}=3,01$ yang berarti bahwa $H_{0}$ ditolak. Maka dari itu dapat disimpulkan bahwa variabel prediktor $\left(X_{2}, X_{4}, X_{7}, X_{10}\right)$ secara simultan atau serentak berpengaruh signifikan terhadap variabel respon (banyaknya balita penderita gizi buruk) dan model tersebut sudah sesuai untuk menggambarkan hubungan antara variabel respon dengan variabel prediktor $\left(X_{2}, X_{4}, X_{7}, X_{10}\right)$.

\section{Uji parsial (Uji t)}

Pada taraf signifikansi 5\%, faktor-faktor $\left(X_{2}, X_{4}, X_{7}, X_{10}\right)$ berpengaruh signifikan terhadap model karena nilai $\left|t_{\text {hitung }}\right|>t_{0.025 ; 16}=2,11991$. Hal ini berarti ada pengaruh antara variabel prediktor $\left(X_{2}, X_{4}, X_{7}, X_{10}\right)$ terhadap variabel respon (banyaknya balita penderita gizi buruk).

\section{Pengujian Asumsi Regresi}

\section{Uji Normalitas Residual}

Nilai sig. $=0.963>\alpha=0.05$, sehingga dapat disimpulkan bahwa error mengikuti distribusi normal.

\section{Uji Multikolinieritas}

Tabel 2: Output Variance Inflation Factor (VIF)

\begin{tabular}{|c|c|c|c|}
\hline Variabel & Nilai $\beta$ & Sig. & VIF \\
\hline$Y$ & 0.223 & 0.935 & \\
\hline$X_{2}$ & -0.203 & 0.032 & 1.355 \\
\hline$X_{4}$ & 0.000 & 0.004 & 1.487 \\
\hline$X_{7}$ & 0.004 & 0.028 & 2.236 \\
\hline$X_{10}$ & 0.001 & 0.024 & 2.167 \\
\hline
\end{tabular}


Pada Tabel 2 memperlihatkan tidak terdapat nilai VIF yang lebih tinggi dari 10 pada variabel artinya tidak terjadi multikolinieritas antar variabel prediktor $\left(X_{2}, X_{4}, X_{7}, X_{10}\right)$ pada model.

\section{Uji Autokolerasi}

Nilai $D=2.224>d_{U}=1.8116$, sehingga $H_{0}$ diterima. Maka dapat disimpulkan bahwa error independen atau tidak terjadi autokolerasi antar errornya.

\section{Uji Heteroskedastisitas}

Pengujian asumsi heteroskedastisitas dilakukan melalui prosedur uji Glejser yaitu dengan cara meregresikan nilai absolut error terhadap variabel prediktor. Pada Tabel 4.10 menunjukkan bahwa nilai sign. $=0.177>\alpha=0,05$ sehingga model tidak signifikan. Maka dari itu disimpulkan bahwa asumsi homoskedastisitas terpenuhi.

\subsection{Spatial Durbin Model (SDM)}

\section{Pengujian Efek Spasial}

\section{Uji Dependensi Spasial (Moran's I)}

Untuk mengetahui dependensi (keterkaitan) spasial pada setiap variabel digunakan Uji Moran's I yaitu dengan melihat indeks Morans atau p-value.

Tabel 3: Tabel Moran's I

\begin{tabular}{|c|l|l|l|}
\hline Variabel & \multicolumn{1}{|c|}{$\mathbf{I}$} & $\boldsymbol{P}_{\text {value }}$ & $\boldsymbol{Z}_{\text {value }}$ \\
\hline$Y$ & 0.179859 & 0.040 & 2.0783 \\
\hline$X_{2}$ & -0.0461775 & 0.041 & 0.0810 \\
\hline$X_{4}$ & 0.0575458 & 0.180 & 0.7846 \\
\hline$X_{7}$ & 0.191874 & 0.070 & 1.7818 \\
\hline$X_{10}$ & 0.703207 & 0.010 & 6.0475 \\
\hline
\end{tabular}

Keterangan : Signifikansi pada $\alpha=5 \% ; Z_{0,025}=1.96$ 
Berdasarkan pengujian Moran's I pada Tabel 3 dengan menggunakan signifikansi $\alpha=5 \%$ diperoleh nilai $Z_{0,025}=1.96$. Nilai $Z_{\text {value }}$ variabel angka gizi buruk $(Y)$ sebesar sebesar 2.0783. Nilai $Z_{\text {value }}$ variabel $Y>1.96$ yang berarti $H_{0}$ ditolak dan disimpulkan terdapat autokolerasi antar lokasi. Nilai $Z_{\text {value }}$ variabel banyaknya rumah tangga miskin $\left(X_{10}\right)$ sebesar 6.0475. Nilai $Z_{\text {value }}$ variabel $X_{10}>1.96$ yang berarti $H_{0}$ ditolak dan disimpulkan terdapat autokolerasi (keterkaitan) antar lokasi.

Pola pengelompokkan antar kecamatan dari tiap variabel dapat dilihat dari Moran's scatterplot. Persebaran variabel banyaknya balita penderita gizi buruk pada Gambar 1 menunjukkan bahwa terdapat pengelompokkan pada kuadran I (High-High) dan kuadran III (Low-Low).

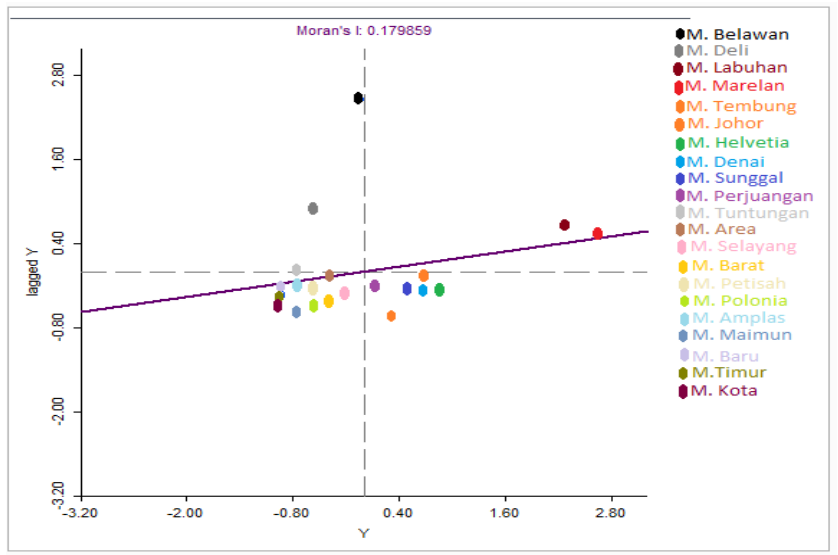

Gambar 1: Moran's scatterplot Banyaknya balita penderita gizi buruk

Pada Gambar 1 diketahui bahwa pola data berada pada kuadran I dan III. Hal ini berarti bahwa kecamatan dengan nilai pengematan tinggi dikelilingi oleh kecamatan dengan nilai pengamatan tinggi juga dan kecamatan dengan nilai pengamatan rendah dikelilingi dengan kecamatan memiliki nilai pengamatan rendah pula. Pada variabel balita penderita gizi buruk $(Y)$, kecamatan yang memiliki banyak balita penderita gizi buruk yang tinggi dikelilingi oleh kecamatan yang memiliki banyak ballita penderita gizi buruk yang tinggi juga dan kecamatan yang memiliki banyak balita penderita gizi buruk yang rendah dikelilingi oleh kecamatan yang memiliki banyak balita penderita gizi buruk yang rendah pula.

\section{Heterogenitas Spasial (Breusch-Pagan Test)}


Untuk mengetahui keragaman atau heterokedastisitas antar wilayah digunakan uji heteroskedastisitas menggunakan Breusch-Pagan test.

Tabel 4: Output Breusch-Pagan test

\begin{tabular}{|c|c|}
\hline \multicolumn{2}{|c|}{ Breusch-Pagan test } \\
\hline BP & $p$-value \\
\hline 1.5016 & 0.9927 \\
\hline
\end{tabular}

Berdasarkan output pada Tabel 4 dapat dilihat nilai pada Breusch-Pagan test sebesar 1.5016. Dengan menggunakan taraf signifikansi $\alpha=5 \%$, diperoleh nilai $p$-value BreuschPagan test lebih dari 0,05 yang berarti $H_{0}$ di tolak dan disimpulkan terjadi heterogenitas spasial antar wilayah.

Setelah dilakukan uji efek spasial, disimpulkan terjadi dependensi spasial pada variabel respon dan variabel prediktor pada uji autokolerasi menggunakan moran's I dan terjadi heterogenitas spasial. Selanjutnya dilakukan analisis pemodelan Spatial Durbin Model $(S D M)$.

Tabel 5: Output Spatial Durbin Model

\begin{tabular}{|c|c|c|}
\hline Variabel & Koefisien & Std.error \\
\hline$Y$ & -15.547 & 4.3855 \\
\hline$X_{2}$ & 0.1465 & 0.085486 \\
\hline$X_{4}$ & -0.000024441 & 0.000024632 \\
\hline$X_{7}$ & 0.0020768 & 0.0010956 \\
\hline$X_{10}$ & 0.0010699 & 0.00049143 \\
\hline Lag. $X_{2}$ & 0.68038 & 0.20304 \\
\hline Lag. $X_{4}$ & 0.0000353 & 0.000065085 \\
\hline Lag. $X_{7}$ & 0.0048815 & 0.0030023 \\
\hline Lag. $X_{10}$ & -0.00037245 & 0.00069706 \\
\hline$\rho$ & -0.93664 & 0.29204 \\
\hline
\end{tabular}


Berdasarkan Output Tabel 5 diperoleh pemodelan menggunakan model SDM yang terbentuk adalah sebagai berikut:

$$
\begin{aligned}
y_{i}=-0,93664 & \sum_{j=1}^{n} w_{i j} y_{j}-15.547+0.1465 X_{2}-0.000024441 X_{4}+0.0020768 X_{7} \\
& +0.0010699 X_{10} \\
& +0.68038 \sum_{j=1}^{n} w_{i j} x_{2 j} \\
& +0.0000353 \sum_{j=1}^{n} w_{i j} x_{4 j}+0.0048815 \sum_{j=1}^{n} w_{i j} x_{10 j}+\varepsilon
\end{aligned}
$$

Adapun $\sum_{j=1}^{n} w_{i j}$ menunjukkan adanya pengaruh lokasi antara kecamatan yang diamati (i) dengan kecamatan yang letaknya berdekatan $(j)$.

\section{Pengujian Model SDM}

\section{Uji Kesesuaian Model SDM}

Keputusan dari uji ini adalah $H_{0}$ (Hipotesa nol) ditolak jika $F_{\text {hitung }}>F_{(\alpha, k, n-k-1)}$. Diketahui bahwa nilai $F_{\text {hitung }}=33.8658>F_{0,05,9,11}=2.90$ yang berarti bahwa $H_{0}$ ditolak. Maka dari itu dapat disimpulkan bahwa model tersebut telah sesuai.

\section{Uji Signifikansi Parameter Model SDM}

Berdasarkan hasil pengolahan data dengan menggunakan taraf signifikansi $\alpha=5 \%$, diperoleh nilai $\chi_{(\alpha, 1)}^{2}$ sebesar 3.84. Nilai wald $Y$ sebesar 12.56767573, nilai wald $X_{7}$ sebesar 4.739833051, nilai wald $X_{10}$ sebesar 11.22896862. Nilai wald variabel $Y, X_{7}, X_{10}$ lebih besar dari $\chi_{(\alpha, 1)}^{2}$. hal ini menunjukkan adanya pengaruh banyaknya balita penderita gizi buruk, banyaknya balita yang mendapat imunisasi lengkap, dan banyaknya rumah tangga miskin.

\subsection{Perbandingan Model Regresi Linier Berganda dengan Spatial Durbin Model (SDM)}

Untuk menentukan model regresi yang terbaik digunakan perbandingan menggunakan nilai $A I C$ dan $R$-square dengan kriteria $R$-square terbesar dan nilai $A I C$ terkecil. 
Tabel 6: Perbandingan model regresi linier berganda metode OLS dan model SDM

\begin{tabular}{|c|c|c|}
\hline Model & $A I C$ & $R$-square \\
\hline $\begin{array}{l}\text { Regresi linier } \\
\text { berganda metode OLS }\end{array}$ & 117.2534 & 0.703 \\
\hline SDM & 111.9631 & 0.965 \\
\hline
\end{tabular}

Dari Tabel 6 didapat bahwa pemodelan gizi buruk dengan model SDM menghasilkan nilai $R$-Square yang lebih besar dari milik OLS, yaitu sebesar 0.965 dan AIC yang lebih kecil, yaitu 111.9631. Maka dari itu dapat disimpulkan bahwa model SDM lebih baik dari model OLS dalam mengidentifikasi faktor-faktor yang mempengaruhi gizi buruk balita di kota Medan.

\section{Kesimpulan}

Dari hasil penelitian menggunakan analisis regresi linier berganda metode Ordinary Least Square dan analisis Spatial Durbin Model, dapat disimpulkan sebagai berikut:

1. Faktor-faktor yang mempengaruhi gizi buruk balita di kota Medan menggunakan regresi linier berganda metode OLS bahwa terdapat satu variabel yang signifikan yaitu $X_{4}$ (penduduk dengan akses berkelanjutan terhadap air minum berkualitas (layak)) dan terjadi multikolinieritas yang ditunjukkan dengan adanya $V I F \geq 10$ maka digunakan metode stepwise backward yaitu mengeliminasi variabel prediktor yang tidak berpengaruh terhadp variabel respon, maka didapatlah empat variabel yang signifikan yaitu banyaknya bayi dengan berat badan lahir rendah, Penduduk dengan akses berkelanjutan terhadap air minum berkualitas (layak), Banyaknya balita yang mendapat imunisasi lengkap, dan Banyaknya rumah tangga miskin.

2. Faktor-faktor yang mempengaruhi gizi buruk balita di kota Medan dengan Spatial Durbin Model (SDM) adalah Banyaknya balita yang mendapat imunisasi lengkap, dan Banyaknya rumah tangga miskin.

3. Pemodelan yang terbaik dan mampu menggambarkan gizi buruk balita di kota Medan adalah Spatial Durbin Model dengan Akaike's Information Criterion (AIC) sebesar 111.9631 dan nilai Koefisien determinasi (R-Square) sebesar 0.965. 


\section{Saran}

Saran-saran yang dapat dikemukakan sebagai berikut:

1. Guna menurunkan gizi buruk balita di kota Medan perlu pengendalian Banyaknya balita yang mendapat imunisasi lengkap, dan Banyaknya rumah tangga miskin.

2. Guna menurunkan gizi buruk balita di kota Medan perlu pengendalian Banyaknya balita yang mendapat imunisasi lengkap, dan Banyaknya rumah tangga miskin.

3. Perlu dilakukan analisis pemodelan spasial dengan menambahkan beberapa variabel independen atau faktor lain.

4. Matriks ketetanggaan yang digunakan pada penelitian ini adalah matriks Queen Contiguity, peneliti selanjutnya dapat menggunakan matriks Rook Contiguity, Bishop Contiguity, atau Linier Contiguiy.

\section{DAFTAR PUSTAKA}

[1] Smith, L. C., dan Haddad, L., (2000): Overcoming Child Malnutrition In Developing Countries: Past Achievements And Future Choices, International Food Policy Research Institute, Washington, D.C.,USA.

[2] Dinkes (2015): Profil Kesehatan Kota Medan tahun 2015.

[3] Anselin, L., (1988): spatial Econometrics: Methods andModels, Kluwer Academic Publishers, The Nederlands.

[4] Ikha, R., (2013): Analisis Faktor-Faktor yang Mempengaruhi Gizi Buruk Balita di Jawa Timur dengan Metode Spatial Durbin Model, Universitas Diponegoro, Semarang

[5] Gujarati, D., (2003): Basic Econometrics, Fourth Edition, McGraw-Hill, New York. Hu, S., (2007): Akaike Information Criterion, North Carolina State University, USA

[6] LeSage, J. P., (1999): The Theory and Practice of Spatial Econometrics, University of Toledo

[7] Kosfeld, R., (2010): Spatial Econometrics, University of Kassel, http://www.unikassel.de/rkosfeld/lehre/spatial.html(Diakses 16 Juni 2017).

[8] Lee, J., dan Wong, D., (2001): Statistical Analysis with Arcview GIS, John Wiley and Sons, New York 